Центр Российских Исследований RRC Working Paper Series Special Issue

Paper Distributed in the Seminor held at Josui Kaikan, Hitotsubashi University on December 9, 2008.

\title{
The soft budget constraint syndrome in the hospital sector
}

\author{
János Kornai
}

November 2008

\author{
RUSSIAN RESEARCH CENTER \\ INSTITUTE OF ECONOMIC RESEARCH \\ HITOTSUBASHI UNIVERSITY \\ Kunitachi, Tokyo, JAPAN
}




\title{
János Kornai
}

\author{
Professor of Economics, Emeritus \\ Harvard University, Collegium Budapest and Central European University
}

\section{The soft budget constraint syndrome in the hospital sector ${ }^{1}$}

This study applies the theory and the conceptual framework of the soft budget constraint (SBC) to the hospital sector. ${ }^{2}$ The first part deals solely with hospitals in state ownership, but the study moves later onto the problems of ownership relations as well.

The group of organizations referred to here as the "hospital sector" covers not only hospitals treating mainly inpatients, but also specialist outpatient clinics and diagnostic or nursing establishments that operate as separate units. These are all referred to as hospitals for brevity's sake.

The study contains several references to Hungarian experience, but it must be made clear from the outset that it does not offer a detailed analysis of the Hungarian situation. The subject is of a more general nature. The SBC phenomenon is not confined to the Hungarian hospital sector, nor to the socialist system, nor as a vestige of socialism to the post-socialist transformation. It is necessarily ubiquitous, even where the context of the hospital sector has been provided by a capitalist market economy.

The question posed here is why the SBC phenomenon is so general in that sector. Before starting to answer that, let me address a charge that can be brought against this choice of subject. I was asked several times during the pre-publication debates whether there was any sense in examining the SBC syndrome in the hospital sector. There are events of earth-shaking importance taking place in the world economy, with bail-outs costing hundreds of billions of dollars being carried out by various countries and international agencies. Softening the budget constraint permeates the international financial system and myriads of firms in the world. In any country the hospital sector is a very thin slice of the macroeconomy by comparison.

That is true enough. Yet I trust that analysis of this thin sector (vitally important though relatively small in size) can offer lessons of general validity. Closure or saving of some hospital is not a world economic event, but it presents many of the same problems found outside the hospital sector. Indeed on certain planes it presents more sharply the motives and behavior of actors and the moral and financial consequences of their actions.

1 I cooperated closely with Csaba Dózsa on collecting and processing the Hungarian data used in this study. His expertise and familiarity with the subject were a very great help in grasping the problems of the situation in Hungary. Csaba Dózsa directed the task of gathering the Hungarian data, in collaboration with others, first of all with Nikoletta Malbaski. I am most grateful for their thorough, circumspect work and their valuable suggestions. I received much notable advice from my former pupil and co-author Professor Karen Eggleston. I would like to thank Zsuzsa Dániel, Péter Forgács, Gyula Kincses, Mária Lipták, Melinda Makár, Péter Mihalicza and Andrea Reményi for valuable support. As with earlier works, Eszter Nagy gave tireless assistance in assembling the literature and editing the study. I express my gratitude to Brian McLean for the excellent translation and to Collegium Budapest and the Central European University for the support of my research.

2 The starting points for the theory appeared first in the paper Kornai (1979) and the book Economics of Shortage (Kornai 1980), since when several other authors have joined in the research. A fresh summary survey of the main theoretical ideas and the various lines of research appear in Kornai, Roland and Maskin (2003). 


\section{The typical chain of events}

Some hospitals operate in a financially acceptable way. In others, income has failed to cover expenditure for a long time and they are obliged to raise loans or simply fail to pay their suppliers, thereby effectively forcing them into lending. Such debt builds up until its volume reaches critical proportions. It swells to a point where the organization - if it happened to be in the commercial sphere-would become insolvent in a legal sense and the court would appoint a receiver.

Figure 1 shows this chain of events. What alternative states can an organization in financial crisis attain? For logical clarity, four clear cases are distinguished, although in reality the cases will be mixed to some extent.

Figure 1

The alternative courses of events for a hospital in financial trouble

The hospital is in grave financial trouble.

Indebtedness exceeds the critical ceiling.

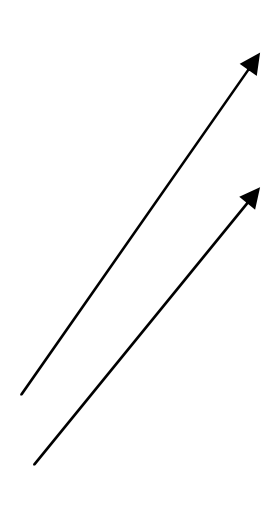

A. It remains in trouble.

B. It ceases to be in trouble because financial equilibrium has been restored by internal means.

Reorganization

Change of profile

Cost-cutting

Income increases

C. It ceases to be in trouble because financial equilibrium has been restored by external means-a bailout.

"Consolidation" (single central government grant)

Increase in regular funding from owner (government, local government)

Extraordinary grant of credit

DRG-correction (raising prices)*

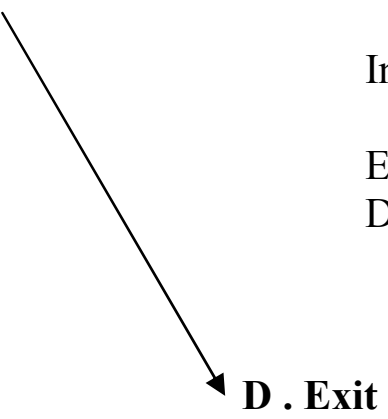

Closure without a legal successor.

Incorporation into another organization.

* DRG $=$ Diagnostic Related Groups - the unit of measurement (in points) for the accounts between the National Health Insurance Fund and the hospitals.

There is no point in repeating what can be read in the figure. But in dealing with hospitals it makes sense to use medical parlance. The organization suffers from a severe illness, for which four possible courses can be envisaged:

A. The illness will persist.

B. The illness will be cured. 
C. The patient will receive first aid and emergency treatment and survive, but the causes behind the symptoms will persist.

D. The patient will die, or as the medical profession and economists put it, there will be an exit - the organism/organization will cease to be.

The key issue for the subject of this study is the degree to which a hospital can expect Course $\mathrm{C}$, which translates into a rescue or bailout. What does it believe? Will it be bailed out if it gets into deep trouble?

Here there have been several misunderstandings about what a soft budget constraint entails. This is a good opportunity to dispel them.

Some imagine that any financial action to save an organization (a firm, a bank, or a hospital, for example) is prima facie evidence of softness of the budget constraint. This is a false interpretation.

The SBC syndrome does not refer to a single event (unlike a bailout, which counts as an event.) SBC is not an event, but a mental condition, present in the head-the thinking, the perception - of a decision-maker. It is a specific type of expectation. My budget constraint is soft if I am expecting (rightly or even wrongly) to be bailed out if any trouble arises. I then adjust my actions to that expectation. It is a hope or belief that has great influence on my decisions, behavior, and actions.

The more frequent bailouts become in my environment, the more I expect the same treatment. (So it involves not one rescue event but many, news of which I digest and adjust my expectations accordingly.) But I may have other reasons to expect a bailout as well. For instance, I may be in a monopoly position, doing indispensable activity, so that I can be sure of not being abandoned. Or I may expect a bailout because I have good connections-political or personal - to those controlling the money for a bailout.

The process is self-inducing. If many organizations expect and receive bailouts, so that they become frequent, even more will come to expect them. And with many organizations, the sequence of events starts again as before, after the bailout, in the knowledge that another rescue will ensue if need be.

Another frequent misunderstanding arises out of the hard/soft pair of terms, as if there were two pure cases - a budget constraint has to be either hard or soft. In fact there are grades of hardness and softness, with many intermediate grades between the absolutely hard and the absolutely soft. Expectations of bailout can be seen a subjective probability in the minds of decision-makers. How probable do they think it is that a bailout will ensue? This indicator is continuous, not discrete, which can assume any value between 0 and 1 .

Let us look at a few graphic examples of the frequency of grave indebtedness and bailout in Hungarian practice. ${ }^{3}$ The data in Table $1-3$ cover the active, publicly financed institutions for in-patients (those financed by the National Health Insurance Fund.) ${ }^{4}$

3 The research preceding this study began with building a database, going back several years, of financial and other operational data for Hungarian hospitals. Expansion of this database is being continued by Csaba Dózsa and his team, and further analyses of the data will be made, to clarify the economic and management problems of the hospital sector.

4 In terms of ownership, the sphere covered by the tables includes not only state-owned institutions but those in church ownership, though these are placed later in the study in a "non-profit, non-state sub-sector." The body of data in the tables is confined to hospitals providing active in-patient treatment and excludes data for separate out-patient institutions. 
Table 1

The number and proportion of hospitals in financial trouble

\begin{tabular}{lcccccccc}
\hline & 2000 & 2001 & 2002 & 2003 & 2004 & 2005 & 2006 & 2007 \\
\hline $\begin{array}{l}\text { Total number of } \\
\text { hospitals }\end{array}$ & 137 & 137 & 137 & 136 & 135 & 133 & 132 & 131 \\
$\begin{array}{l}\text { Number of hospitals } \\
\text { in financial trouble }\end{array}$ & 31 & 30 & 21 & 12 & 36 & 24 & 53 & 39 \\
$\begin{array}{l}\text { Proportion of all } \\
\text { hospitals in financial } \\
\text { trouble (\%) }\end{array}$ & 22.6 & 21.9 & 15.3 & 8.8 & 26.7 & 25.6 & 40.2 & 29.8 \\
\hline
\end{tabular}

Note: A hospital is "in financial trouble" if its end-year stock of overdue debt to its suppliers exceeds 3 percent of its annual expenditure.

Source: Database compiled by Csaba Dózsa and colleagues. The main sources of data included in the database were the database of the Health Care Strategic Research Institute and the indebtedness surveys of the Ministry of Health.

The following criterion was applied to Table 1: a hospital is "in financial trouble" if its overdue debt to its suppliers at the end of the year exceeds 3 percent of its annual expenditure. $^{5}$ It is apparent in the table what a high proportion of hospitals are in financial trouble. In most years, one hospital in four or five began the year in grave financial difficulties. The proportion in 2006 was higher still, 40 percent.

Track was kept of the 42 units that were in financial trouble in mid-2002. ${ }^{6}$ It emerges from Column A of Table 2 that many of the group of 42 had already been in trouble, but remained in a critical state despite the efforts and bailouts designed to overcome financial crisis.

Special heed needs paying to the bracketed data in the column. These figures reflect rescue operations that assisted the troubled hospitals, but did not suffice to push the debt below the critical value.

Column B shows favorable developments in the sequence of events. In these it proved possible for internal forces to push the debt below the critical value. ${ }^{7}$

5 The threshold value chosen is the one used for appointing state (treasury or local-government) administrators to take charge of indebted hospitals. It is close to the criteria for sending in receivers in the corporate sphere.

6 Mid-year rather than year-end figures were consciously chosen for the selection. The accounting system focuses on year-end figures, as do the reports of the hospitals (and other bodies) to their owner-institutions, the tax office, etc. But the special heed paid to the December 31 position means that some skill goes into embellishing the figures for it. Revenues are brought forward, expenditures postponed, and so on. There are no such incentives to manipulate the position on June 30 , when the real problems appear more clearly.

7 It was not possible from the data available to isolate the case in the group of 42 where internal and external means were combined, i. e. expenditure cuts and healthy income increases coincided with a rescue operation. These mixed cases were assigned to one pure case or the other, according to which course was more characteristic in treating the financial woes. 
The prior and subsequent records of 42 hospitals in financial trouble in 2002

\begin{tabular}{cccccc}
\hline Year & $\begin{array}{c}\text { A } \\
\text { In trouble }\end{array}$ & $\begin{array}{c}\text { Not in trouble: resolved by } \\
\text { internal means }\end{array}$ & $\begin{array}{c}\text { C } \\
\text { Not in trouble: resolved by } \\
\text { external means (bailout) }\end{array}$ & $\begin{array}{c}\text { D } \\
\text { Exit }\end{array}$ \\
\hline 2000 & 17 & $(5)$ & 17 & 8 & 0 \\
2001 & 22 & $(10)$ & 12 & 8 & 0 \\
2002 & 19 & $(17)$ & 4 & 19 & 0 \\
2003 & 8 & $(3)$ & 27 & 7 & 0 \\
2004 & 19 & $(8)$ & 17 & 6 & 0 \\
2005 & 15 & $(5)$ & 16 & 10 & 0 \\
2006 & 21 & $(10)$ & 12 & 5 & 0 \\
2007 & 16 & $(9)$ & 17 & 9 & 5 \\
\hline
\end{tabular}

Notes: The table considers the situation pertaining on December 31 of the year concerned. Selection of the group of 42 units observed was made according to their position at the end of June 2002.

The numbers in parentheses in Column A are the numbers of units where the central or local government performed a significant rescue action in the year concerned, yet failed to bring the debt down below the critical value, i. e. the units remained "in trouble."

Source: Database compiled by Csaba Dózsa and colleagues. The main sources of data included in the database were the database of the Health Care Strategic Research Institute and the indebtedness surveys of the Ministry of Health.

Column $\mathrm{C}$ shows the bailout operations. Adding together for each year the figure in Column $\mathrm{C}$ and the bracketed figure in Column A reveals how many bailouts took place-full or partial, resulting in a rescue or only ameliorating the troubles. For instance, there were $19+$ $17=36$ bailouts in the observed group in 2002, the base year. These were accompanied in many cases by reorganization and other cost-cutting measures. The result over six months was that only 19 of the organizations were still in trouble by the end of the year.

Hospital spending began to be curbed more severely in $2002 .^{8}$ Though further measures to restrict expenditures were taken in the 2004-6 period, it is clear from Table 2 there were no exits until 2007: survival was guaranteed! This really is a clear sign of the SBC syndrome. True rigor appeared in 2007, when one third of the financially incapacitated hospitals were closed by administrative order, either by being liquidated without a successor or merged with other, viable organizations.

Some of the bailouts were small-scale, of an ad hoc nature. But alongside these "tailor-made" rescues, there were huge bailout operations on two occasions, in 1996 and 2002. These are known as "consolidations" in Hungarian parlance. Table 3 gives some data on the two big consolidations.

8 In 2004 so-called "performance volume" restrictions were introduced. A ceiling was placed each year on the total volume of output for which the National Health Insurance Fund will offer 100 percent funding. If output volume exceeded the ceiling additional payment followed by a decreasing scale. The higher the output of the hospital, the smaller is the marginal payment. Many argue about whether this radical central intervention is an effective instrument of cost containment. promoting the efficiency of operation. Thorough examination of the question is beyond the scope of this article. 
Table 3

Some features of the state consolidation programs in 1996 and 2002

No. of organizations affected

Sum in HUF

Proportion of sum to the total amount paid by the National Health Insurance Fund

Number of beneficiaries of the 1996 consolidation to benefit from the 2002 consolidation
38 30

4 billion

3.5 billion

$6 \%$

$3.8 \%$

N/A 16

Source: Database compiled by Csaba Dózsa and colleagues. The main sources of data included in the database were the database of the Health Care Strategic Research Institute and the indebtedness surveys of the Ministry of Health.

It is worth noting that after that first bailout in 1996, the number of hospitals in financial trouble fell substantially. Here it is worth looking back at Tables 1 and 2, which show the fall clearly. But it was only temporary. Thereafter the number in trouble rose again. A bailout could be expected and was built into the expectations, so that overspending increased. Almost half the beneficiaries from the big 1996 bailout experienced financial trouble again. Here the SBC syndrome is almost palpable.

\section{Table 4}

The appearance of the SBC syndrome in the hospital sectors of other countries

\begin{tabular}{ll}
\hline Country & Literary source \\
\hline Austria & OECD [1997a] \\
Chile & Perry-Leipziger (ed.) [1999] \\
Finland & OECD [1998] \\
Greece & OECD [1997b] \\
Luxembourg & OECD [1999] \\
Norway & Hagen-Magnussen-Kaarboe [2007]; Tjerbo-Hagen [2008] \\
Italy & Bordignon [2000]; Bordignon-Turati [2003] \\
Switzerland & Colombo-Zurn-Oxley [2006] \\
Sweden & Rae [2005] \\
United States & Newhouse [1993]; Duggan [2000]; Capps-Dranove-Lindroth \\
\hline
\end{tabular}

Note: The list does not include post-socialist countries. 
Considerations of space prevent detailed quotations from works presenting similar occurrences in the state hospital sectors of many other countries. So Table 4 merely lists the countries for which information on the appearance of the SBC syndrome has been found. It also cites the sources on which the assertion that the SBC phenomenon can be found there is based. $^{9}$

So this broadly constitutes to the plot of the drama. What has not been discussed so far is the cast.

\section{The behavior of the main characters}

This section focuses on five of the many cast members: the patients, doctors, hospital managers, politicians, and owners. There are obviously other important characters, such as the pharmacists, the medical schools, the ministry supervising the health service, and the managers and clerks of the health insurance scheme. But the five listed characters seem sufficient to express the main lines of argument in this study.

Two questions need answering for each. What motivates them and how they behave as a result of the incentives received.

\section{The patients}

Ultimately, all activity in the hospital sector is done for the patients' benefit. The patients' motive is to recover as quickly and as fully as possible, while suffering and encountering discomfort and exploitation as little as possible.

This usually involves higher expenditures. Though patients are not expressly happy to see hospital costs rise, they push for such extra spending so that their goals can be met. They would like the hospital doctors to listen to their complaints patiently at a personal meeting. If need be, the latter should obtain new information to diagnose and treat the complaints found, and consult with colleagues. All in all, this means devoting more medical time to treatment. There is a similar demand on nurses' time: they should devote greater attention and concomitant working time to patients. Financially, this increases costs at constant pay levels.

Furthermore, patients would like doctors' and nurses' pay to be raised, as they believe better-paid staff will do their work with more care.

Patients would like more spent on material conditions as well as staff ones. They believe they will suffer less and recover faster and more fully if the latest equipment is used to diagnose and treat them, and if they are prescribed the latest (and usually more expensive) medicines devised by scientific research. Moreover, patients also want to be as comfortable as possible while in hospital. All these aspirations drive up costs.

These are quite rational, understandable aspirations. Such extra spending benefits patients in most cases. Even if there are opposite occurrences-more expensive treatment or medicines are not always better - there is a strong positive correlation between quality and cost.

So patients exert strong forces for extra expenditure. Where there is a co-payment mechanism whereby patients make a small cost contribution out of their pockets, there is a modest counter-incentive, although patient pressure to raise expenditures does not cease.

9 Some of the literature cited in Table 4 employs the terminology of SBC theory. Some uses other expressions (talking, for instance, of the causes, distribution and effect of organizational exits), but in such a way that the presence of the SBC syndrome can be followed without a doubt. 
Without co-payment, the patients' interest in higher spending is unhindered. ${ }^{10}$

Let us think what it means to patients if rising expenditures push the hospital into deficit. Let us assume the gravely indebted hospital closes - organizational exit takes place.

The patients win and lose. If a closed hospital is absorbed into another, well-run hospital or treatment concentrated without a formal merger, that may benefit the overall quality of treatment. It may allow specialists and expensive equipment to be concentrated.

Patients and their families are taxpaying citizens. The taxpayers save paying back the losses of organizations with financial troubles.

But these advantages, hard to perceive and not immediately apparent, are offset by direct, immediately apparent drawbacks. Patients lose an accustomed doctor and environment when a hospital closes. Many patients and their families find themselves further from the available hospital. This in unpleasant, meaning longer journeys and higher travel costs. If treatment is required urgently, there is a danger in arriving later at the venue for treatment, or even grave, irreparable problems. ${ }^{11}$

So news of a hospital closure makes patients grumble or even protest publicly. They are natural allies of those seeking a bailout for the hospital.

\section{The doctors}

Doctors are seen in several lights. Some portray them as saints, devoted to their job and interested in nothing but patients' welfare. But some believe doctors are mainly greedy people, only after the money.

Both pictures are distorted. Doctors have many motivations, each with an effect on them, in individual proportions, of course. All these must be grasped before the doctors' part in the SBC syndrome can be understood.

Doctors seek to further their patients' recovery. The link between patients' interests and hospital-care costs has just been mentioned. The more doctors identify with patients' interests, the more obliged they feel to spend more of the hospital's money. The inducement to allow the patient to stay in hospital for longer, receive more expensive drugs, or enjoy costlier diagnosis and treatment is enhanced if rewarded by patients with gratuities. ${ }^{12}$

Apart from service to patients and linked with it, there is doctors' professionalism and professional ambition to impel them toward cost increases. They are predisposed by their desire to keep pace with technical and scientific development predisposes to use the latest, usually more costly, ostensibly more effective drugs, diagnostic procedures and equipment, medical aids, surgical techniques, and so on.

Opposing the inducements to spend more is a sober realization that available resources are finite. This insight may be backed by administrative curbs, tight cost controls, or financial incentives to hold back costs.

Inducements to spend and administrative, financial, and moral spurs to curb spending

10 The larger is the share of co-payment, the stronger is the counter-incentive. There has long been co-payment in many foreign countries, including some in Western Europe. It was introduced in Hungary in 2007, but a 2008 referendum led to all forms of co-payment being withdrawn, including co-payment for hospital care.

11 The US researchers Capps, Dranove and Lindrooth (2006) performed cost-benefit calculations on gains and losses of hospital closures. Their approach to the latter was mainly to calculate the car-travel time to the closed hospital and to the nearest hospital still operating. The difference in hours was multiplied by average hourly pay to give a money value for the extra travel. The authors, of course, took this simply as a proxy for the loss to the consumers. As the description underlines, the loss combines several factors, including recovery chances and risks of life and death.

12 Paying gratuities to doctors is a wide-spread phenomenon in the post-socialist region. 
are the opposing forces acting on doctors. But clearly the former are very strong, and this (the propensity to overspend and override the budget constraint) is the factor sustaining the SBC syndrome. This is the "natural state," which doctors' instincts dictate, whereas the counter-motives they must impose on themselves or have forced upon them.

If protracted breaches of the budget constraint lead to the idea of closing the hospital, doctors working there will usually protest. They obviously fear for their jobs, but anxiety is not the only factor, as they have good chances of work elsewhere. They sympathize sincerely with the nervous protests of the patients. They request or noisily demand a bailout for the hospital in chronic financial trouble. Such protest has a dramatic effect, and if participants like, the matter can be dramatized further. Once the press, radio and television are involved, other members of the public will be outraged, if only for fear of being similarly affected one day. All this fuels public pressure for a bailout.

The effect of the protest becomes stronger (and justifications more convincing) the closer the threatened hospital is to a monopoly position. Here it is immaterial whether the monopoly subsists only in a territorial sense (one hospital for a given area) or whether the hospital is a unique institution (specializing in treatment of some organ and possessed of expensive, high-performance equipment). Once that monopoly position has been recognized, the threatened hospital can expect a bailout: the powers that be cannot watch idly as it closes for financial reasons. So doctors, counting on a bailout, can continue more easily to overspend. The more concentrated the hospital sector-the less scope for competition within it and for one hospital's activity to substitute for another's - the bigger the chance of a bailout, i. e. the softer the budget constraint. ${ }^{13}$

\section{Hospital managers}

The motivation is similar to that of doctors. Managers on the one hand represent the interests of patients and doctors. But on the other they are under pressures opposite to those felt by their employees. They (not the employed doctors) are held responsible for the indebtedness. Hospital managers are under twin pressures: they sympathize with the spending propensity of their underlings but they are the ones who must curb it.

It is hospital managers above all who perceive the $\mathrm{SBC}$ as an expectation. If rescue is not 100 percent certain, they above all must lobby for the bailout. The stronger the hospital manager's position is in relation to the hospital's superior organizations, the insurer providing the funds and the institutional owner providing the subsidy, the greater the hope of rescue. So hospital managers often take the lead in protesting against exit, or orchestrate the protest themselves.

The ambivalence in hospital-manager behavior is partly explained by ambivalence in the relation between the hospital's financial crisis, the bailout, and dismissal/appointment of managers responsible. If a hospital gets into financial trouble and there are strong reasons for saving it, not closing it, there should at least be deep investigation of who is responsible for the trouble. A thorough investigation should establish what blame attaches to the hospital manager. It is no task for this paper to answer that hard question, but it is disquieting that six of the managers of Table 3 hospitals undergoing consolidation remained in the saddle throughout. $^{14}$

13 There are also problems in a purely economic sense with improving hospital-sector performance through mergers and concentration. On the one hand there are economies of scale: a bigger unit operates at lower average costs. But on the other the resulting restriction of competition weakens the incentives to cut costs, undermines financial discipline, and establishes the SBC syndrome.

14 Nowadays, as great rescue operations take place in all spheres of the economy all over the world, the demand is heard ever more frequently: let the bailout always involve dismissal of the managers 


\section{Politicians}

Politics can be eliminated from hairdressing services or brewing and beer sales (perhaps not wholly, but they can be called processes that are almost free of politics). But it is impossible to eliminate politics from the regulation of health care. The funding and the direction, scale and methods of state intervention in health care will always be a political concern in a modern welfare state.

There are two common kinds of distorted view of politicians. One is that they are motivated by nothing more than a lust for power; they will do anything to be popular, gain votes and win political supporters. The other, found among enthusiastic supporters of certain politicians, is that they are apostles of great and noble ideas.

In fact politicians are driven by various motives. To stay with the subject of closing financially troubled hospitals, politicians do not view such an event gladly - they sympathize sincerely with the patients and doctors, sharing their chagrin and outrage. But whether or not their empathy with patients and their families, friends and acquaintance is sincere, they will fear their anger because they are voters. They need their political support. Robinson and Torvik (2006) go so far as to call the influence of popularity-driven politicians on bailouts a fundamental cause of the SBC syndrome. I see this as a one-sided, exaggerated assumption but there is some truth in it.

On the other hand, politicians know that to condone overspending and tolerate a soft budget constraint reinforces the SBC syndrome. Though they may not think through the whole causal chain, it is clear to them that frequent breaches of organizations' budget constraints and repeated rescue operations contribute to a macro-level budget deficit that leads to grave, painful macroeconomic problems and associated political difficulties.

Politicians are especially sensitive to the perils of repeated bailouts and the burdens placed on the budget if they support the government side. Politicians in opposition are easily enticed onto the side of those protesting against closures. It is instructive to look at Norway's experience of this.

Dagfinn Hoybraten, a Christian Democrat who served as health minister in 2001-4 in a liberal/conservative coalition government, had this to say of the volte-face by the previously governing social democratic party: "The Labor Party [when in power] complained of the softness of the budget constraint... and initiated hospital reform. ${ }^{15}$ But when they went into opposition they forgot everything they had said before and opened fire [on the new government] as the hospitals had begun to complain about their crisis." $" 16$

The Italian economist Bordignon (2000) says it is especially hard for a government to make a firm pledge not to rescue loss-making institutions if it is based on a fragile coalition that may easily and frequently break down. So the phenomenon is traceable to the system of proportional representation. This may also have an effect, but the hardness is not easily maintained even if the government lasts its political term, or even if it is re-elected.

The Norwegian and Italian examples show that the SBC syndrome appears under conservative, liberal, social democratic, left wing, or right wing governments alike (Hagen and Magnusen-Kaarbo 2007, Tjerbo and Hagen 2008, Bordignon 2000, Bordignon and Turati 2003).

It is noticeable that politicians use their influence more intensively if they belong to

of the organization in trouble (bank, industrial corporation, etc.) It has been proposed in some countries that there should be legislation to this effect.

15 Regardless of who may be right in the political conflict, I cannot deny being flattered as an author to find Norwegian politicians using the expression "soft budget constraint" in their debates.

16 The quotation is from Tjerbo and Hagen (2008, p.15.) 
the same political grouping as the head of a troubled organization. A hospital stands a better chance of a bailout if it is led by someone from the governing political forces. The term for this coined in an article on Indian experience by S. A. Dasgupta, A. Dhillon and B. Dutta (2003) is the "alignment effect". This features as a separate variable with a softening effect in econometric models for analyzing budget constraint on the Italian state hospital sector, presented in a study Bordignon and Turati (2003), and proves to be significant.

Similar conclusions emerge from Hungarian cases. For example, any big state bailout (consolidation) has a better chance of rescuing the hospital if it is "close"(as Hungarian journalists put it) to the political forces governing the country at the time. ${ }^{17}$

The alignment effect is enhanced by the well-known post-electoral practice of changing not only the central or local political regime and those performing political functions (ministers, mayors, and the level of hierarchy just below them), but many other posts lower down. A new local government tries to appoint those close to it politically to any jobs deemed significant, in municipally owned firms or schools, or even the management of a theatre. ${ }^{18}$ Nor does the hospital sector seem immune to this practice of switching managers. ${ }^{19}$

Politicians have good reason to act this way. Two authors cited earlier, Robinson the American and Torvik the Norwegian economist, used in an article (2006) on the political motives behind the SBC the expression "clientalist" for such exchange transactions. Politicians redistribute benefits and gain political support in return through the patron/client relationship.

\section{Digression: central and local government}

It is well worth including in this sequence of events the middle level: local government. In many countries, a lot of the publicly owned hospitals belong to the local, not central, government.

It is quite common, especially in Europe, for the constitution or the law to state that local government is responsible for the health care of its residents. On the other hand, the constitution or the law in force for a lengthy period does not specify what financial resources are supposed to cover the local governments' needs. Is there enough revenue to fund the expenditure (including development) not covered by health insurance or co-payments? If local government in general (and in connection with health spending in particular) is reliant on funds from central government, how are the costs to be divided between central and local government?

There are as many cost-dividing processes and proportions as there are countries and political/governmental periods. There will inevitably be bargaining between government and local forces. And if some organization under local-government management (a municipal transport provider, a school or a hospital) gets into financial trouble, who pays to rescue it?

17 Subsequent politically impartial analysis of each bailout would be the one way to establish how strong the alignment effect is in Hungary - what influence such "proximity" or "distance" may have on allocation of rescue funds. Without such studies, the remarks above reflect only impressions of experts familiar with the situation. Further study by impartial researchers would be desirable.

18 This is known in my family as the "cabin attendant effect." My wife was once told by a taxi driver that he used to earn more as a swimming-bath cabin attendant. Why had he left, then? Because a new manager had been appointed after the elections and brought his own attendants with him.

19 What I said in Note 16 about allocation of rescue funds applies equally to the practice of appointment and dismissal. Want of thorough, politically impartial investigations leaves only guesswork to rely on. Let us hope this important problem will be addressed in future research. 
The SBC syndrome provides a feverish accompaniment to this battle. ${ }^{20}$

The phenomenon is familiar to Hungarians and frequent elsewhere. Local government in Italy, for instance, has responsibility for health care but not capable of paying for the costs itself. But the scale of its contribution is not laid down. There are repeated bouts of bargaining and repeated bailouts (Bordignon and Turati 2003). Hospitals are restricted in what they may borrow from banks, but local governments are not. So it is not the hospitals (or likewise the schools or the retirement homes) that get into debt directly, but the local governments that support them and rescue them if they overspend. Nor is it the hospitals (or other municipal organizations) that have to be rescued, but the local governments as direct financers of them. This can be seen in the data of Table 5, from which it emerges what a high proportion of the bailout costs are then taken over from local government by the center.

Table 5

Italy: proportions of deficit to bailout 1995-9

\begin{tabular}{lclc}
\hline Region & $\begin{array}{l}\text { Sum provided by central } \\
\text { government as a proportion } \\
\text { of accumulated debt (\%) }\end{array}$ & Region & $\begin{array}{l}\text { Sum provided by central } \\
\text { government as a proportion } \\
\text { of accumulated debt (\%) }\end{array}$ \\
\hline Piedmont & 55.45 & Lazio & 53.31 \\
Lombardy & 50.96 & Abruzzo & 56.41 \\
Veneto & 44.60 & Molise & -2049.00 \\
Liguria & 34.57 & Campania & 36.82 \\
Emilia-Romagna & 47.19 & Puglia & 33.36 \\
Tuscany & 40.77 & Basilicata & -577.49 \\
Umbria & 8.41 & Calabria & 26.81 \\
Marche & 56.08 & All & $\mathbf{5 2 . 5 6}$ \\
\hline
\end{tabular}

Note: A minus amount means that the region concerned received a greater amount than its accumulated debt.

Source: Bordignon-Turati [2003], Appendix table A1

How can the problem be solved? Should the ownership of public hospitals and the duty to fund them be centralized or decentralized? Norway tried decentralizing, but overspending appeared. Then it centralized, only for overspending to appear again. (See Tjerbo and Hagen 2008).

The propensity to overspend and the tendency for a SBC to appear is rooted far more deeply. It is a far more strongly motivated social phenomenon than mere reorganization, centralization, decentralization, or recentralization campaigns could overcome.

20 Here this study is related to the constantly increasing literature on the connection between the SBC and fiscal decentralization. See studies by Qian és Roland (1998) and Rodden (2000), and the volume edited by Eskeland, Litvack and Rodden (2003). 


\section{Deficit and handing debt upward}

Figure 2 shows vertical relations between the main actors analyzed so far.

Figure 2

Vertical relations: "passing up" deficit and debt

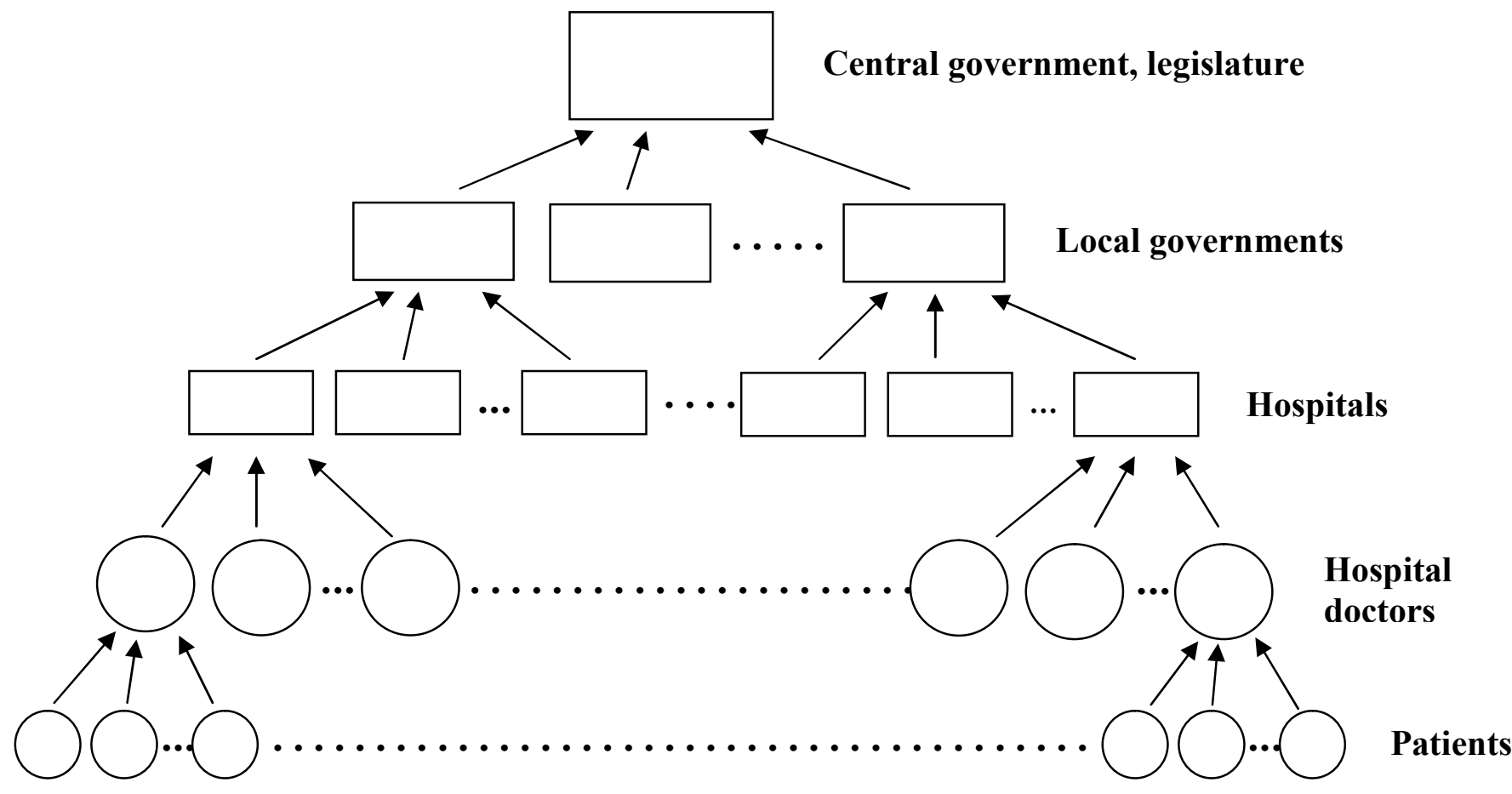

The little circles on the bottom level represent the patients. On the highest level is central government and the legislature. The actors at every level have an incentive to hand upward the overspending and the consequences of breaching the budget constraint.

Patients encourage doctors to overspend.

Doctors push hospitals into overspending and rising indebtedness.

Hospitals try to shift the deficit and debt caused by overspending onto the government, local or central, depending on which is the owner. The established practice is for the latter to take on the cost of the overspending.

Local government tries to pass the cost onto the central government. If there are several layers of local government (e. g. city, county and province, in larger countries), the handing-up process may include these.

Once the trouble has come, the deficit is unsustainable, and the debt insupportable, the decision-making layers above the patients begin to blame each other and bandy the responsibility about among them. ${ }^{21}$

Here it is worth placing a methodological observation into the description and analysis. The approach taken bears a resemblance to the outlook of behavioral economics. It is not confined to generalizations about actors' utility-maximizing goals. Instead the intention is to understand the special inducements essential to the phenomenon examined (in this case

${ }^{21}$ The situation is well expressed in the phrase "blame game." This develops as the actors blame each other. 
softening of the budget constraint). The goal is to find the motivation that induces in the actors the behavior that produces the phenomenon.

At one point the study exceeds the descriptive method characteristic of behavioral economics. Special heed is paid to mutually contradictory inducements. There are conflicting forces at work on an actor (within the subject under examination, e. g. the hospital manager or the politician). To repeat the remark made earlier, hospital managers are under twin pressures. Who should they show solidarity with? Staff and ultimately patients? Or those who appointed them to manage public money well? There is conflict within politicians as well. Should they go for popularity or for statesmanlike responsibility? If legislators, for instance, happen to belong to the government side, who should they be responsible to: the citizens in their constituencies complaining about a local hospital closure, or the national public represented by the legislature, whose interests are damaged severely by budget deficit or high taxes to pay for repeated bailouts?

The situation discussed here only exemplifies a wider phenomenon. There is no peace of the decision-makers' mind obliged to take a stand on difficult problems. There are no settled, firm, consistent preferences. They wriggle and waver, now saying and wanting one thing and now the opposite.

One school of theoretical modeling of the SBC stresses its time inconsistency. (This was explored in an influential paper by Dewatripont and Maskin 1995, which has been followed by several other theoretical analyses.) The rescuer makes a preliminary promise not to bail out the troubled organization, hoping thereby to elicit observance of financial discipline and budget constraint. But if trouble still comes, it breaks its promise. It finds some subsequent reasons why a bailout is rational. This inconsistency between consecutive events (preliminary promise, subsequent bailout) is one psychological basis for inconsistency in the concurrent features of the decision-maker's thinking (and feelings).

\section{The effect of ownership relations}

To return to the main line of argument after that methodological observation, there are five main actors to be considered, of which the owner's behavior has scarcely been touched on.

The study so far has looked only at the public sector, with central or local government as the owner. This shows a deep-running propensity to overspend and breach the budget constraint, coupled with strong rescue motives, so that organizations inclined to overspend can justifiably expect a bailout. This fuels a spiral of repeated overspending and bailout.

What is the case with private ownership? There are two kinds to consider: for-profit and non-profit. Both, in Anglo-Saxon parlance, belong to the private, not the public sector. With the latter, the owner may be a foundation, association, non-state educational institution, church, etc. ${ }^{22}$ Non-profit organizations in many countries receive tax concessions, so that the state contributes indirectly to their running costs.

The American economist M. G. Duggan (2000) conducted an interesting investigation into a state program in which the state paid a specific sum to hospitals for a specific medical purpose. In the municipally owned hospitals, nothing happened at all. The local governments simply "swallowed" the money, as they reduced their support for the

22 It is interesting to see in historical terms the changes in the proportions between ownership forms in the United States. In 1928, there were 371,000 hospital beds, 31 percent in state, 53 percent in private non-profit, and 16 percent in private for-profit hospitals. By 2000 the number of beds had more than doubled to 824,000, but the proportions were quite different: 16 percent in state, 71 percent in private non-profit, and 13 percent in private for-profit hospitals. The non-profit form had become dominant. (See American Hospital Association, Hospital Statistics.) 
hospitals by the amount being received under the special program. But in the non-state sector-both the non-profit and the for-profit sub-sectors - the effect of the extra funding was felt in about equal intensity.

I have yet to find a survey giving a reassuringly conclusive answer to the question of how hardness/softness of the budget constraint relates to ownership form. The comparative studies were mainly done in the United States, where the various ownership forms have long coexisted and relatively large amounts of data are available. Certain suppositions can be made from the work I have met with (e. g., Succi, Lee and Alexander 1997, Chakravarty, Gaynor, Klepper and Vogt 2005, David G. 2005, Capps, Dranove and Lindrooth 2006, Eggleston 2008, Eggleston and Shen 2008, and Shen and Eggleston 2008), but I must add that these are just suppositions that need further testing. These suppositions appear in Table 6.

\section{Table 6}

\section{The relation between ownership form and chance of bailout}

Ownership form

Public

(central government or municipal ownership)
Chance of rescue from financial trouble

Huge

Private

Not great but not inconsiderable

Non-profit

For-profit

Small but not negligible

The main behavioral dividing line does not run between public and non-profit on the one hand and for-profit on the other. Far stronger is the line between the public, state sector and the private, non-state sector.

It has been discussed in the present paper that the budget constraint is inevitably more or less soft under the public, state form. The non-state ownership form is where scope lies for hardening the constraint, though that is not certain either.

As for the two kinds of private, non-state form, non-profit hospitals have a greater chance of bailout than for-profit organizations do (Capps, Dranove and Lindrooth 2006). But bailouts in the hospital sector are not wholly ruled out even under the for-profit form. A for-profit hospital may also receive a bailout, for instance if it has a territorial or professional monopoly, or good personal connections with the governing political forces.

I have explained in earlier writings how I am a believer in having various forms of ownership coexist in health care. I would not recommend countries to institute campaigns of hospital privatization, but I would urge them not to erect bans or barriers to central or local government handing over some or all of the hospitals in their ownership to non-profit or for-profit organizations, or allow non-state organizations to operate hospitals without a change of ownership taking place. More importantly still, the door should be wide open for non-state undertakings to enter, if they meet strictly the special quality requirements of health care. The entry of non-state companies and private capital must be combined with reinforcement of government regulation and control. (See the book on health care reform written by myself with Karen Eggleston 2001, especially Chapter 7.)

There are several arguments for admitting non-state (non-profit or for-profit) businesses into the hospital sector. Such initiatives should be encouraged principally where capital and investment are offered, i.e. a commitment is made to modernize and expand. 
Private resources are much needed to augment state resources in health-care development. It can be hoped that non-profit and for-profit enterprises will make health care more economic. These are primary arguments, but it is also worth weighing the secondary argument that non-state hospitals are more likely to observe financial discipline and it is easier to harden the budget constraint on them.

Regardless of the proportions in which various forms of property appear in the hospital sector, it is desirable that hospitals compete for patients, not the reverse - patients for hospitals. The competition should be on the supply side, not the demand side. This is a key condition for hardening the budget constraint. No institution in a monopoly position can be abolished however poor its economic performance may be. It is a hopeless and self-contradictory policy to perform great mergers while advertising financial discipline. The threat of exit can only apply if there is a body capable of taking over from the failed organization.

\section{Normative conclusions}

The study so far has approached the SBC syndrome from a positive angle. I would like here to turn briefly to normative problems. Many economists are inclined to draw utterly simplified normative conclusions from the practical observations and theoretical assumptions about the $\mathrm{SBC}$, such as that a hard budget constraint is good and a soft one bad, or that all bailouts soften the budget constraint and should therefore be avoided.

To begin with my own position, so primitive and extreme a normative position is quite alien to me and can be found nowhere in my writings. That applies to many other researchers into the SBC, who do not veto all bailouts either.

The issue gains further immediacy from the events of today's financial crisis, which include massive bailouts in the United States, Europe and other parts of the world. Only fundamentalist economists with blind faith in market infallibility could imagine there was no need anywhere to bail out any organizations in financial trouble. It is not the task of this paper to adjudicate on bailing out the banks and other financial organizations, or at a later stage in the crisis, the insolvent production companies unable to obtain credit. What has to be weighed in their case is the destruction caused initially to the financial system and ultimately by the knock-on, spillover economic effects on production and employment. The subject here calls for consideration of another set of indirect effects (e. g. on the health-care situation and standard of treatment of the public), and although analogies appear in the way the questions are put, it would go beyond the scope of this paper to enumerate them.

This is precisely because the subject is hospitals, not banks or car factories, and the dilemma has a conspicuous ethical content. ${ }^{23}$ There is no denying that hardening the budget constraint may decrease treatment quality and impede access to it. Karen Eggleston and Yu-Chu Shen (2008) examined how hospitals reacted to the hardness of the budget constraint. The conclusion was the well-known drawbacks of a softer constraint were not the only effects. It also made it easier to apply better-quality treatments that were more effective but more expensive at the same time. Hospitals less threatened by insolvency found it easier to introduce these, which could help to strengthen the "safety net" and reduce mortality.

To state the dilemma in a more general form, what happens if a hospital in financial trouble is closed? What advantages and drawbacks ensue?

The drawbacks are sensed immediately and individually by all concerned, in a way internalized into their own lives. (It is harder to access accustomed treatment; doctors lose

\footnotetext{
${ }^{23}$ On the normative dilemma attaching to the hard budget constraint and its relation to the welfare net, see Hardy (1992).
} 
accustomed working conditions.) But the advantages of refraining from a bailout are delayed. They appear later as stronger financial discipline, more efficient management, slower growth in expenditure, and a smaller burden on the taxpayer. ${ }^{24}$ All these benefit society as a whole, but they are not experienced as individual achievements. They appear as largely intangible external effects.

Do we want to help today's patients now or should we be thinking of the future too? If resources for health care are used badly, we ultimately rob future patients to treat present ones better. Repeated bailouts turn into a bad teaching method in the long term, encouraging irresponsibility.

There is no self-evident solution to these ethical dilemmas, and so this paper does not lead to clear practical conclusions. I cannot offer a simple, clear rule of thumb for potential rescuers (ministers, legislatures, mayors, local governments, etc.), either one way- "once a grave financial crisis has arisen in a hospital it should always be rescued"- or the other- "regardless of the size of a hospital's debt it should never be rescued." I cannot recommend either stance as a universal rule. The grant or denial of a bailout has to depend on the given circumstances, a final account of all the advantages and drawbacks of closure or rescue.

By no means should bailouts be initiated automatically. Each case has to be considered separately. If the decision after conscientious consideration is a bailout, it must be performed in the knowledge of inevitable longer-term drawbacks, notably future erosion of financial discipline. Such damaging effects can be mitigated to some extent in such cases. For instance, it can be stated clearly what led to the crisis. Was it outside circumstances alone? Or, as in most cases, was there human error as well, typically on the part of the management? It is not enough to establish responsibility. Those responsible must suffer the personal consequences. It is unacceptable to use public money to rectify the mistake while leaving those who committed it in charge, drawing their high salaries unimpeded. Where there is a repeated bailout operation the discipline must be sterner still.

External aid must be coupled as closely as possible with internal measures: cost-cutting, better work organization, heightened expenditure controls.

Because there is no ubiquitous rule for accepting or rejecting a bailout, hesitation before taking a decision becomes a fact of life. The normative dilemma can here be fed back to the positive analysis. If all actors (doctors, hospital management, central and local politicians, owners, and others so far unmentioned, such as commenting journalists and investigating researchers) are gripped by the tough ethical dilemma, that further strengthens society's resistance to the SBC syndrome.

\section{Summary conclusions}

The appearance of a SBC in the hospital sector is not peculiar to Hungary, or to the post-socialist region. It is propensity that necessarily applies also under modern, democratically governed capitalism, where state ownership, state regulation, and state financing have a necessarily great role to play. Furthermore, it reproduces itself, retreating but resurging after a time.

This does not mean standing idly by. Much can be done to prevent this propensity from becoming too strong. Moral and financial incentives must be applied to combat the tendency to overspend. Such overspending should not be passed through automatically. If the circumstances offer pressing arguments for bailing a financially troubled hospital out with

24 The favorable effects of closing an inefficient hospital are presented in a thorough empirical survey in Lindrooth, Lo Sasso and Bazzoli (2003). 
state resources, this must be accompanied by close investigation of how the troubles arose and by bringing those responsible to book. The way must be opened for the entry of non-state forms of ownership, among other reasons because there are improved chances of hardening the budget constraint on private businesses. It is desirable to have supply-side competition in the hospital sector.

All these things require effort. But in battling against softening of the budget constraint, let us not do so in a blind, dogmatic, blinkered or extreme way, as fanatical market fundamentalists, but in a humane way, taking into account not only the justifiable opposition, but even the erroneously grounded anxious antipathies of patients and doctors.

\section{REFERENCES}

AMERICAN Hospital Association, Hospital Statistics, www.aha.org

Bordignon, M. [2000]: Problems of Soft Budget Constraints in Intergovernmental Relationships: The Case of Italy. Inter-American Development Bank Working Paper \#R-398, Washington D. C.

Bordignon, M. - G. TURATI [2003]: Bailing Out Expectations and Health Expenditure in Italy. CESIFO Working Paper No. 1026, München.

Capps, C. - D. Dranove - R. C. Lindrooth [2006]: Hospital Closure and Economic Efficiency, Center for Health Industry Market Economics, Kellogg School of Management at Northwestern University, Evanston.

Chakravarty, S - M. Gaynor - S. Klepper - W. B. Vogt [2005]: Does the Profit Motive Make Jack Nimble? Ownership Form and the Evolution of the U. S. Hospital Industry, NBER Working Paper 11705, Cambridge, MA.

Colombo, F. - P. ZuRn - H. OxLey [2006]: OECD Review of Health Systems/Switzerland, OECD, World Health Organization, OECD Publishing, Paris.

Dasgupta, S. - A. Dhillon - B. DutTa [2008]: Electoral Goals and Center-State Transfers: A Theoretical Model and Empirical Evidence from India, forthcoming in: Journal of Development Economics http://www2.warwick.ac.uk/fac/soc/economics/staff/faculty/dhillon/wp/grantsmail4.pdf (Downloaded: 02.09.2008.)

DAvid, G. [2006]: The Convergence between For-Profit and Nonprofit Hospitals in the United States, Annual Meeting Allied Social Science Associations, 2006.

Dewatripont, M - M. MASKIN [1995]: Credit and Efficiency in Centralized and Decentralized Economies, Review of Economic Studies, Blackwell Publishing, vol. 62(4), $541-55$

Duggan, M. G. [2000]: Ownership and Public Medical Spending. The Quarterly Journal of Economics, Vol. 115, No. 4, (Nov., 2000), pp. 1343-1373

EGGLESTON, K. [2008]: Soft budget constraints and the property rights theory of ownership, 
Economics Letters 100, pp. 425-427.

Eggleston, K. - Y. Shen [2008]: Soft Budget Constraints and Ownership: Empirical Evidence from US Hospitals, Working Paper

ESKELAND G. S. - J. I. LiTVACK - J. RodDEN (eds.) [2003]: Fiscal decentralization and the challenge of hard budget constraints, MIT Press.

Hagen, T. P - J. Magnussen - O. M. KaARboe [2007]: Centralized or Decentralized? A Case Study of the Norvegian Hospital Reform. Social Science \& Medicine 64, Vol. 10, $2129-2137$

HaRDY, D. C. [1992]: Soft Budget Constraints, Firm Commitments, and the Social Safety Net. IMF Staff Papers, Vol. 39., No. 2.

KoRNAI, J. [1979]: Resource-Constrained versus Demand-Constrained Systems, Economitrica. Vol 47, Issue 4, pp. 801-819.

KoRNAI, J. [1980]: Economics of Shortage, North-Holland, Amsterdam.

Kornai, J. - K. Eggleston [2001]: Welfare, ChOICE AND SOLIDARITY IN TRANSITION REFORMING THE HEALTH SECTOR IN EASTERn EuROPE, CAMBRIDGE UNIVERSITY PRESS, CAMBRIDGE, ENGLAND.

Kornai, J. E. MASKIN - G. Roland [2003]: Understanding the Soft Budget Constraint, Journal of Economic Literature, Vol XLI., pp. 1095-1136.

Lindrooth, R. C. - A. T. Lo SASso - G. J. BAzzoli [2003]: The Effect of Urban Hospital Closure on Markets, Journal of Health Economics 22, 691-712

Newhouse, J. P. [1993]: An iconoclastic view of health cost containment, Health Affairs 12 (Supplement) pp. 152-171. http://content.healthaffairs.org/cgi/reprint/12/suppl_1/152.pdf (Downloaded 14.11.2008.)

OECD [1997a]: OECD Economic Surveys Austria 1996/1997, Volume 1997, Issue 5, OECD Pubishing, Paris

OECD [1997b]: OECD Economic Surveys Greece 1996/1997, Volume 1997, Supplement 1, OECD Pubishing.Paris.

OECD [1998]: OECD Economic Surveys: Finland 1997/1998, Volume 1998, Issue 15, OECD Pubishing, Paris.

OECD [1999]: OECD Economic Surveys: Belgium/Luxembourg 1998/1999 Volume 1999 Issue 4, OECD Pubishing, Paris.

Rae, D. [2005]: Getting Better Value for Money from Sweden's Healthcare System, OECD Economics Department Working Papers No. 443, OECD Publishing, Paris

Perry, G. - D. M. LeIPZIGer (eds.) [1999]: Chile: Recent Policy Lessons and Emerging Challenges, World Bank Publications, Washington D.C.

QIAN, Y. - G. Roland [1998] Federalism and Soft Budget Constraint, American Economic 
Review 88:5, 1143-62.

Robinson, J. A. - R. TORVIK [2006]: A Political Economy Theory of the Soft Budget Constraint, NBER working paper 12133 http://www.nber.org/papers/w12133 (Downladed: 28.08.2008.)

RodDEN, A. [2000]: Breaking the Golden Rule: Fiscal Behavior with Rational Bailout Expectations in the German States, Prepared for the Workshop: European Fiscal Federalism in Comparative Perspective, Center for European Studies Harvard University http://web.mit.edu/jrodden/www/materials/brescia2.pdf (Downloaded: 02.09.2008.)

Shen, Y. - K. EgGleston [2008]: The Effect of Soft Budget Constraints on Access and Quality in Hospital Care, NBER Working Paper 14256

Succi, M. - S-Y. F. LeE - J. A. AleXANDer [1997], Effects of Market Position and Competition on Rural Hospital Closures, Health Services Research 31(6) 679-699.

TJerbo, T. - T.P. Hagen [2008]: Deficits, Soft Budget Constraints and Bailouts: Budgeting after the Norvegian Hospital Reform, Manuscript, Insitute of Health Management and Health Economics, Univerity of Oslo, Oslo. 